Kohl: a Journal for Body and Gender Research

Vol. 6, No. 2 (Fall 2020)

\title{
"Nobody is going to want her like this:" Disability, Sexuality, and Un/Happiness in Kyrgyzstan
}

Mohira Suyarkulova 


\section{The origin story: positionality and dual researcher/activist identity}

"Nobody is going to want to fuck her now," my ex said to her once-best friend, who is now my assistant. They are namesakes and my ex's ex-friend, Sasha, is now taking care of me - cooking delicious vegan meals, cleaning my rental apartment, going shopping for groceries. She has become my only company on most days. My ex did not visit me in the hospital while I was awaiting and recovering from surgery. She only appeared several weeks after I was discharged and spending all the time in bed, still too weak to get into a wheelchair. "Now you cannot run away from me," she said only half-jokingly, unable to contain her schadenfreude.

In late August of 2017, I went to a birthday party celebration at a queer night club in Bishkek. "London" is a migrating bar owned by a lesbian couple, the only place in Kyrgyzstan's capital city where non-heterosexual and gender non-conforming people can gather, flirt, make out, dance, drink, and feel like they are part of a community. They have to move often because it is not safe to stay in the same place for a long period of time.

On that warm August night, I drank and chatted with my friends, I think I kissed a girl I slow-danced with, I bought drinks for the birthday boy, and stumbled out of the bar and into a taxi around four in the morning. I do not recall what happened after because at some point during what was supposed to be a short trip home, an SUV driven by a drunk officer of Kyrgyzstan's Financial Police collided head-on with the taxi. I was seated in the back of the car and the impact of the collision brought about a head injury, which resulted in brain concussion and partial amnesia. Besides the head trauma, with lots of lacerations to my face and a lost front tooth, both of my femur bones were broken. I remember being taken to the hospital by an ambulance and then waking up in the intensive care unit.

I was lucky to survive, but my injuries meant that I had to undergo surgery, which turned me into a cyborg with titanium plates and screws inside both of my legs. It also meant that I had to depend on the care and support of my relatives, friends, and hired stay-at-home round-the-clock nurses for six months. Since then, I have learned how to walk again and had to re-organise my life around my new limitations. I now have chronic pain - it varies from sharp sciatica pain that debilitates me for a week or constant dull pain in my lower back and down my thighs that makes it hard to sit and walk.

Throughout the months of when I was locked in my little apartment, located on the fourth floor of a building constructed in the 1960s with no elevator, I turned to the internet to learn more about this new disabled life. I found a community of mutual help on social media, and videos by wheelchair users in Russia, who live in similar urban landscapes to the one I found myself in, teaching wheelchair use basics and more advanced techniques of going down and up the stairs in a wheelchair - which I did not dare risk. Thanks to my 
knowledge of English, I also discovered queer disabled bloggers like Jessica Kellgren-Fozard and Annie Segara. I knew Mia Mingus' work from the time I translated her science fiction story, "Hollow" (Brown and Imarisha 2015), into Russian for a queer science fiction book (Shatalova and Mamedov 2018) published by a queer communist collective called STAB (School of Theory and Activism Bishkek). So I started identifying positively and politically as a person with a disability. Even though I have had a visual impairment since I was in third grade, which has only deteriorated over the years, I never identified as disabled before this car crash. Through contact lens wearing, I could "pass" as not disabled before. It never limited my life in a way that I could not overcome while remaining invisible.

Because of this situation, my mother came from Russia to care for me. Her presence in my life in this more day-to-day intimate way resulted in me coming out to her, which literally broke her heart - she ended up in the hospital with a heart irregularity. "I just want you to be happy and healthy," she said to me, the unspoken reproach being, "Why can't you be happy like everyone else?" My aunt came to Bishkek from Moscow to take my mother to a hospital in Russia. From then on and for several months, I relied on hired nurses to take care of my basic needs. This meant they also had to stay overnight in my apartment. This also meant that I had to hide my personal life from them and live in the conditions of a general lack of privacy.

You learn who your true friends are in situations like this. Who is going to hide your sex toys and strap-on from your mother when she comes to stay in your apartment? Who is going to delete your ex's nudes from your phone now that other people have access to it? Who is going to help you get dressed, wash your hair, go to the bathroom? Who is going to bring you "forbidden" foods and the latest gossip? Who is going to include you in their plans even though it would mean hiring a private ambulance and a whole team of paramedics to carry you down the stairs and into their venue where the event is taking place?

These are some of the roots of my research interests in the issues of sexuality and disability. In January of 2018, while still recovering from my injuries, I started a research project on sexual lives of LGBTQ+ people in Bishkek, Kyrgyzstan. The purpose of this participatory research project was to create a comprehensive and inclusive queer sex education curriculum, which would be based on real experiences and needs of LGBTQ+ folks in Kyrgyzstan, without shame, fear, or medicalisation of our lives. ${ }^{1}$ Later on, colleagues from

\footnotetext{
1 The 2018 study was conducted in collaboration with Bishkek-based LGBT organisation "Labrys" and funded by a small grant from Grindr Equality. The co-researchers, recruited from the community and trained in research and data collection methods, conducted over 90 in-depth biographical interviews focusing on sexual histories of the respondents, their gender identities, body image and relationships. Issues of disability also came up in these interviews and this analysis will incorporate some of this data.

Undertaken in the fall and spring semesters of the 2018-19 academic year, the study collected new primary data with a particular focus on people with disabilities - mostly those diagnosed with cerebral palsy and the hard of hearing/deaf persons. I have conducted two small focus groups (one with three women with cerebral palsy and one with two hard of hearing women), and four individual in-depth interviews. An expert interview was also conducted with Galina Chirkina, the head of the Reproductive Health Alliance (partner of IPPF in Kyrgyzstan).

The help of the sign language interpreter was required during the interviews with the hard of hearing and deaf people, which both facilitated and complicated the communication between the researcher and the respondents. I am not sure if some meanings were lost or acquired in the translation. It became apparent that the presence of another person
} 
the American University of Central Asia (AUCA) and I started a project on the psychological wellbeing of people belonging to marginalised and vulnerable groups (the elderly women, persons with psychiatric diagnoses, LGBTQ youth, and people with disabilities). We called this project "the happiness project." Finally, in July 2019, I took part in the Global Feminist LBQ* Conference in South Africa, where I attended a workshop on disability and sexuality and met Kohl editors. In this essay I am going to reflect on the intersections of these seemingly disparate interests of mine - sexuality, disability and happiness. This is where the personal becomes the political, where a deeply private experience is translated into sociological imagination, where the activist and the scholar in me merge into a single self.

\section{"Feminine Happiness:" Compulsory heterosexuality and compulsory able-bodiedness}

In the post-Soviet space, there is a special conception of happiness for women - it is called exactly that, a "womanly [or feminine] happiness" (zhenskoie schastie in Russian). A popular song from the 1990s, "Womanly happiness," performed by Tatiana Ovsienko describes what exactly is meant by zhenskoie schastie: an idyllic heterosexual marriage and domestic bliss whereby the woman is "protected" by her husband and takes care of all his needs in return. In its everyday usage, zhenskoie schastie also includes having children - a woman's happiness is never complete without the experience of motherhood. Feminine happiness is conceptually distinct from simply happiness. More tellingly, there is no corresponding concept of a "manly happiness." A man's happiness is simply happiness. In other words, zhenskoie schastie is the notion that encapsulates within itself simultaneously compulsory sexuality (Emens 2014), compulsory heterosexuality (Rich 1980), compulsory motherhood/procreation (Shchurko 2012), as well as compulsory able-bodiedness (McRuer 1999) and compulsory happiness (Davies 2015). Women with disabilities, nonheterosexual and gender non-conforming individuals, the childfree and infertile, the asexual, the depressed, the disabled cannot be included in this model of happiness, which implies productivity and ability/willingness to reproduce as the main measures of one's human worth.

Happiness and its pursuit have become the new normative regime, a teleological end-all of human existence in a neo-liberal society. The various critics of this condition have pointed out that the ideology of personal happiness and the "happiness industry" it has generated are utilised by capitalist regimes to appease individuals with the condition of the ever-growing social wretchedness. From Arlie Russel Hochschield's ground-breaking The Managed Heart: Commercialization of Human Feeling that studies the emotional work (mostly undertaken by women) in the new service economy, to more recent examples of the analyses of the political economy of feelings, like Barbara Ehrenreich's (2009) Bright-Sided: How Positive Thinking is Undermining America and William Davies' (2015) The Happiness Industry: How the Government and Big

\footnotetext{
made some respondents uncomfortable and reluctant to share some aspects of their sexuality and experience. It obviously also meant that this set of respondents did not speak under the conditions of confidentiality, although I promised to anonymize the transcripts. In one case, a young man with limited hearing described his past romantic and sexual relationship as heterosexual in the presence of the interpreter, and then wrote to me personally via a messenger to clarify that he was in fact speaking of a male partner when talking of that relationship. All respondents' names and identifying details have been changed here.
} 
Business Sold Us Wellbeing, time and time again the authors observe how the imperative of compulsory happiness actually renders the neo-liberal subjects more miserable, shifting responsibility from the agents generating the root causes of unhappiness onto the individuals themselves. They argue that the dictates of positive thinking and "McMindfulness" result in self-blame, political passivity, and ignorance, producing suitable subjectivities for the precarious workplace and consumer markets.

Criticism of the compulsory happiness has not only appeared as part of the Marxist analysis of the contemporary human condition, but also from feminist and queer theorists and scholars. As early as 1963, Betty Friedan launched the second wave of American feminism with her analysis of the deep misery experienced by educated white middle class women in suburbs, who were supposedly living the American dream in Feminine Mystique. In a post-Soviet Central Asian context, this is comparable with the abovementioned concept of "feminine happiness" (zhenskoie schchastie) with compulsory heterosexual marriage and childbirth and rearing as its core components and the only possibility to experience subjectivity offered to women. Such idealised life-scenario is obviously rooted in ableist and cisheterosexist imagination, thus denying happiness and fulfilment to all those who do not fit the mould - the queers, the disabled, the elderly, the unmarried, the childfree.

The promise of happiness that is thought to be only achievable through "domestic bliss" is not actually fulfilled in reality: a recent study demonstrated that the happiest demographic group are single women without children (Dolan 2019). Critical social scholars argue that our societies are so obsessed with marriage and romance (Bella DePaulo coined the term "matrimania" to refer to this phenomenon) that uncoupled individuals are discriminated against, stereotyped as weird, undesirable, and miserable, or simply ignored despite the fact that the singles are the growing demographic (the majority in fact in a lot of developed countries today) that most people tend to be part of at some point in their lives (Kislev 2019). Eva Illouz (2007) and Laurie Essig (2019) have both criticised the modern cult of love from a materialist point of view. Illouz' book Why Love Hurts: A Sociological Perspective describes the pursuit of love as a difficult and painful experience, but instead of attributing this pain to individual inadequacies and failures, she argues that we hurt because of the "institutional forces shaping how we love." Similarly, in her recent book Love, Inc. Dating Apps, the Big White Wedding, and Chasing the Happily NeverAfter, Laurie Essig describes romantic love as an ideology we turn to in the absence of real social, economic, and political agency - the modern-day "opium of the masses" so to speak.

Feminist Sara Ahmed introduced the concept of "affect aliens" to describe all those who are not made happy by the things that are supposed to make them happy and whose unhappiness is perceived as creating unhappiness rather than reflecting the misery of their existence. The feminist killjoy, the melancholic migrant, the unhappy queers, and the raging revolutionaries are the "willfull subjects" who are alienated from happiness, "out of line with an affective community" (Ahmed 2010, no page). We can also add the "sad crip" to this list of affect aliens, since people with disabilities are also excluded from the common scripts of happiness, love, sexuality, and affection. 


\section{The will to (self)knowledge and hermeneutical injustice of denial of sex education}

The sexuality of disabled people is rarely discussed in Kyrgyzstan. ${ }^{2}$ It is partially due to the general lack of adequate language for talking about sexuality outside of the traditional patriarchal framing of sex as only related to reproduction. Queer people and the disabled are denied subjectivity because they are not seen as full mature rational people. Disables people are thought of as either asexual (they never have sex and have no interest in it) or hypersexual (cannot and will not say no to sexual advances since they are not seen as desirable partners). Especially women with disabilities are often denied reproductive choices and therefore their sexualities become invisible and stigmatised. The issue of sexual consent gains special salience in the context of disability, while sexual desire and practice are often talked about in biologised and medicalised terms (as a hormonally-induced compulsion).

Feminist theorisation of disability views disability, like gender and race, as a "pervasive cultural system that stigmatises certain kinds of bodily variations" (Garland-Thomson 2002, 5). Historically, cultural stereotypes have conflated categories of naturalness, femininity, sexuality, and ability, whereby politics of appearance, desirability, and compulsory heterosexuality slide into metaphors of health/illness, humanness/monstrosity, normalcy/aberration, associated with discourses on disability. Authors working in the field of feminist disability studies have long pointed out the intersections between politics of appearance and the medicalisation of subjugated bodies of women, the queers, and the disabled.

Disabled bodies have long been subjected to attempts to fix them, eradicate them, make them "docile" and invisible in order to advance some idea of human happiness and perfection. Beliefs and practices such as selective abortions, assisted suicides, euthanasia, eugenics-inspired mass killings of the "feeble and the infirm," institutionalisation, and isolation are manifestations of the desire to expunge non-normative bodies from the field of visibility and deny them existence. This has to do with the modern phantasms of totality and purity, with cultural visions of what a perfect society should be like: devoid of illness, where rationality rules and supermensch move unhindered toward their destinies. Writing on the issue of selective abortions to prevent disability, whereby arguments in favour of the practice use the "quality of life"/"prevention of suffering" logic, Adrienne Asch and Gail Geller (1996) pointed out the impossibility of either predicting in advance or

\footnotetext{
2 The term "disability" includes a wide range of psychological and physical conditions and chronic illnesses. Within the framework of this modest study, I talked to people with cerebral palsy and different degrees of hearing impairments. One interview (from the queer sex study with Labrys) was with a transman who was born without a right hand and with a heart condition. Cerebral palsy is a movement disability that appears in early childhood and can manifest as a range of symptoms: stiffness and weakness of muscles, tremors and poor coordination, as well as problems with sensation, vision, hearing, swallowing, and speaking. Hearing loss and deafness also exist on a spectrum with different respondents within this study having varying abilities for communication with hearing people and non-hearing people (cochlear implants, knowledge of sign language, ability to lip read and articulate). Some non-hearing people do not consider their condition an illness but rather a difference and view efforts to "cure" deafness as attempts to erase deaf culture. This is consistent with the social constructivist view (social model) of disability - the idea that it is not a certain condition in itself that is disabling but rather the way societies and infrastructures are organised around normative "abled" bodies that are disabling to non-normative bodies.
} 
controlling such "equivocal human states as happiness, suffering, or success" (cited in Garland-Thomson 2002, 16).

I argue that the denial of sexual education to disabled people is a type of epistemic injustice - a hermeneutical one. The concept of epistemic injustice was coined by Miranda Fricker in 2007. She particularly identifies two types of "wrong done to someone specifically in their capacity as a knower" $(2007,1)$ : testimonial injustice and hermeneutical injustice. Testimonial injustice takes place when one's credibility is questioned due to their social identity or status. Women along with other marginalised groups have long suffered testimonial injustice, whereby they are not considered to be credible witnesses to their own lives (Solnit 2014). Hermeneutical injustice is a specific kind of socially produced ignorance, resulting from a lack of understanding of one's experience and/or social identity because there does not exist an appropriate category of interpretation. Such categorizations are absent because it is in the interest of a dominant group to keep people from developing them. For instance, imagine experiencing postpartum depression, sexual harassment, or being a homosexual at the time when these concepts did not yet exist. Similarly, people with non-normative bodies being denied knowledge about important mental, physiological, and social aspects of their lives, being denied the possibility of a full sexual being, limits their ability to make sense of their lived experiences and to politicise these lived experiences.

My respondents have varying levels of education. Some never went to school and are functionally illeterate; others only went to school for one year before being transferred to home-schooling (due to discrimination and bullying), and some others have a high-school diploma and a technical training in professions like seamstress, programmer, or printing house worker. None of the respondents had a higher education.

None of the respondents ever received formal sexual education at school, most getting information about sex from peers and from pornography. In one case, a gay man with a hearing impairment attended a training on STIs and HIV prevention conducted by a local LGBT organisation (Kyrgyz Indigo). One respondent, when asked about his experience with sex education, replied:

No. None. What did we have in our libraries? Lermontov, Pushkin [Russian classical authors]. Nothing of that kind. When we grew a bit older, first VCR-players appeared and the porn. We would run to the neighbour's windows at night knowing that they would be watching porn to peak through their windows and got information about how to have sex like that (Mir, transgender man, no hand, heart condition, 40).

This lack of sex education is partially due to the general omission of any discussion of sex and sexuality from the school curricula and public discussion. The only contexts where sex is usually talked about are part of the institutions of marriage and procreation.

The burden of virginity, "having a baby for oneself," and being a good kelin 
Cultural stereotypes imagine disabled women as asexual, unfit to reproduce, overly dependent, unattractive - as generally removed from the sphere of true womanhood and feminine beauty. Women with disabilities often must struggle to have their sexuality and reproductive rights recognised. Since women with disabilities are often not viewed as desirable marriage partners or potential partners, they are denied knowledge about sex. Sex for pleasure is not talked about as a possibility. At the same time, women with disabilities either experience reproductive pressure and coercion as denial of their reproductive choices (for fear they would produce more disabled people and/or would not be able to care for their children), or are told that they must give birth early (even if there is no prospect of marriage) - to have a child "for yourself," thus implying that under "normal" conditions children are produced for someone else?

- (Respondent 1) Sometimes my mother tells me, get married, you need to become a mother. Relatives tell me, you may not get married, but just have a baby.

- (MS) And do you want to have children?

- (Respondent 2) Yes, I do. My brothers and mother tell me, at least you must give birth. Ok, you may not get married, but give birth for yourself. And then we will help you.

- (Respondent 3) Relatives say so, my mother, because she understands me. But I don't want to have children this way, I also want a family. If I have a child like this, the paternal side of the family will say: it happened like this because she is disabled. And they will say you are ill and your child will be ill too. A gynecologist once suggested to me that I should get sterilised because I won't be able to take care of a child. (A focus group discussion with women with cerebral palsy)

Disabled women who might not want to get married and have children, but rather have sex for pleasure thus become completely invisible within this patriarchal matrix. Moreover, they simply may not be able to do so due to lack of access to useful information on sexual practices and safety, barriers to their mobility, inability to meet potential partners, and have privacy since many live with relatives and depend on others as caregivers. For instance, a young woman (25) with cerebral palsy told me that she would like to explore her sexuality but is worried that tense muscles would not allow her to engage in penetrative sex. She was also worried about unwanted pregnancy and sexually transmitted diseases. Another woman (33 years old) said that she had sexual experience, but after she got caught cuddling with her boyfriend at home, she was called a slut and since then has to go to a hotel for love-making (for which they do not always have money).

In my room there is no latch on the door. And even if I wanted to install one, my relatives would ask why would you want to have it. So I do not have a space to look at my own body, to masturbate. When I had a boyfriend, I wanted to have sex but I wondered - where? (Begim, ciswoman, cerebral palsy, 25)

There is a lot of shame, guilt, and fear attached to expressing one's sexuality outside of marriage. In the focus group discussion with women with cerebral palsy, they repeatedly used the words "it's scary" and "I am scared," and talked about the requirement to stay a virgin before marriage. Their relatives threatened to disown them should they have sex before marriage and they themselves witness the rituals and conversations, whereby virginity of a new bride had to be demonstrated through display of the bloody sheets 
after the first marital night. My respondents asked me to explain where exactly this "virginity" was located and how could they make sure that they would not lose it by accident.

Another issue of concern and great anxiety at the prospect of marriage was whether their disability would prevent them from fulfilling the duties of the new bride (kelin) who is expected to shoulder all the domestic and care labour of her husband's household - a back-breaking toil that is unbearable to many able-bodied young women. In one case, a hard of hearing woman (35-year-old) was put out of the house by her in-laws for "being lazy" and "sleeping too much." Her mother-in-law and sister-in-law expected her to work full time during the week as a seamstress and then come to their village on the weekends and do a lot of house work there, including tending to cows and other hard chores, all while nursing a newborn child.

His mother demanded a full report of my earnings, how much I make as a seamstress, how much in state pension. And the sister-in-law also mistreated me. They both were after me. And when I gave birth, I thought they would help me, because of my condition, but they said, "it was your decision to have a child." Through my husband she took away all my earnings, saying it was "for safekeeping." (Noor, hard of hearing ciswoman, 35)

Later when her mother-in-law suggested that the sister-in-law should breastfeed her child, she refused, as she felt it was a major encroachment onto her identity as a mother and wife. The in-laws were scandalised and offended by her refusal and put her and her child out of the house. Since then her husband would visit her in secret. He gradually got more insecure, possessive, and violent with her. He is now married to another woman, but continues secretly seeing Noor. She is scared of him and does not know how to end the relationship. When asked about what her wishes for the future were, she said she did not want a husband, but really wanted to build a house of her own.

\section{Happiness on different terms}

People with disability who do not adhere to the normative ideas of beauty and sex-appeal may struggle with accepting their bodies and therefore experience issues in their sexual lives. However, in some cases, disability can be liberating from the restrictive gender roles and expectations. Banishment from femininity can be both a liability and benefit. The gender non-conforming respondent told us how he eventually succeeded in his struggle to dress in boys' clothing:

As long as I can remember myself, from age 5 I knew that I did not want to wear dresses [...] So I did not. But still up to the age of 30 , no, even up to 33 years, the pressure continued. My mom still tried to pressure me into it. She would see me with a girl and ask "sooo, you are a lesbian?" And I had to deny everything, that I am not that kind of person. And my physical flaw played a big role in this. The fact that I do not have a hand allowed me to stand against people's gossip. I could use the excuse that because of the fact that I do not have a hand, I need to wear trousers, because dresses do not have pockets. All of this even helped me. So I did not suffer because of this shortcoming, it 
was alright. [...] I still experience internal discomfort in my body - because of my heart condition I cannot undergo another surgery. I had a heart surgery and so I cannot take hormones or have a surgery, because I have already been anesthetized 6-7 times before. So I am a little scared of this now, plus I do not want to bring shame onto my mother. [...] I do not even need to change my ID documents. I simply want to have the top surgery. This is a dream within me, but I know that I cannot do that. [...] Let God forgive me for using the fact that I was born with an anomaly. This anomaly helped me in my life. (Mir, transman, no hand, heart condition, 40)

This intersection of gender-nonconformity and disability enables our respondent to live outside the normativities of both cis-heteronormativity and the beliefs of what it means to be a transgender person. But code-switching in different environments also works as a security-navigation measure:

I have no discomfort with either "she" and "he." All these years I have been switching automatically - at work and at home I am "she," on the street, "he." I switch automatically. I allow my better half to call me whatever she likes - even "it," if she wishes, as long as it suits her. I love you, and I do not care what the others would say. This is not permissible to others, obviously. [...] Sometimes, even often, it happens that because my partner has a child, we cannot tell him everything and so at their house like at my own home I have to go by "she." But on the street I am a completely different person. (Mir, transman, no hand, heart condition, 40)

Although family home is usually normatively described as a safe space of care, unconditional love, and acceptance, in reality for many both home and the streets can be marked as unsafe spaces. Both spheres are made inaccessible and dangerous to non-normative bodies and psyches. Women with disabilities, for instance, experience higher rates of sexual harassment and assault both in their homes and on the streets than women on average. In my interviews all women reported experiences of lewd propositions from taxi drivers, passersby, groping on the public transport, inappropriate touching and unwanted physical contact from people close to them whom they trusted, partner violence, and abuse in relationships. My respondents told me how complete strangers on bus stops asked them how they have sex or assumed they would be happy to be propositioned (disabled women are assumed to be desperate for sex because they are viewed as undesirable partners) or agree to sex work. Oftentimes disabled people themselves internalise these beliefs and because of the fear of loneliness and poverty accept abusive and unsatisfying relationships. Our transgender respondent tells the story of how he met his current partner:

When I was 33 years old I was in a car accident and broke the left arm, I had a surgery and all. I spent a long time in the hospital. And this feeling of loneliness, this feeling of fear... It was a really horrible year for me. And for about two years after that I really suffered. I would lie down and think, when will I meet my other half. And finally I did. Out of desperation when I was still lying in a cast at home, I put up a personal ad in the newspaper called "Blitzinfo," saying that I would like to meet a girl. [...] I said openly that I am disabled in this ad so that there would be no issues afterwards. I even remember that I bluntly wrote that I am looking for a sponsor. Yes, it was even like this, because I was in such a desperate situation, I did not care any longer. I sort of did not give a shit anymore 
about myself. I simply had to survive somehow. Who would hire me now... And so we are still together. This is my story. (Mir, transman, no hand, heart condition, 40)

Economic dependence and exploitation by partners and their families were also a common theme in my interviews. All respondents reported that the state pension/welfare payments are not nearly enough to even pay the utility bills, let alone to afford living expenses. Oftentimes having one job is not enough to support oneself. Thus, for instance, the young hard of hearing man (22) worked two jobs (as a barista in two coffee shops and at a printing house) and earned about 18,000 KGS (around 200 US dollars). He could not convince his employer at the printing house to give him the vacation he was entitled to and was considering leaving that job since it paid very little. Disabled people have a poor negotiating position on the labour market due to additional burden of discrimination and inaccessibility. For many disabled people whether they are capable of gainful employment or not depends on their relatives and partners. This may influence their romantic lives as relatives often prevent them from forming loving relationships with "undesirable" partners (in two cases people said their mothers did not allow their relationship/marriage to a person because of that person's ethnicity). In one extreme case, my respondent's close friend committed suicide, burning down the garage she shared with her two children and husband. In the news this incident was reported as a result of a conflict between the hard of hearing woman and her mother-in-law. According to the reports, the mother-in-law sold the land that the couple were allocated for building a house and appropriated the money, while promising her son and his wife that they could live together at her house. However, contrary to that promise, she put them out of their house and they had to live in a garage which was not suitable for living (the incident occurred in February of 2019). ${ }^{3}$

Remarkably, when asked how they envisioned a happy living, most of my respondents did not refer to domestic bliss or romantic stories. Rather they saw work, creativity, sport, and being part of a community as the main sources of psychological well-being.

Marathon running helps me to keep balance, all nerves, all kinds of thoughts. [...] When I run, I don't think about anything else, I just run. [...] I am happy that I have found marathon running. It makes me happy to be alive. (Sasha, hard of hearing, gay cisman, 22)

\section{Conclusion}

Any serious promotion of happiness needs to embrace not just the personal, but also efforts to change a larger world that so firmly impedes possibilities for greater joy in the lives of so many. Or, at least, the pursuit of happiness must refuse to abandon the desire to see such a change. - Lynne Segal (2017: xv)

\footnotetext{
${ }^{3}$ https://www.currenttime.tv/a/29767997.html
} 
This study puts into stark relief the impossibility of a "private" happiness project within major social injustices. The inability to participate in the matrimonial sexual project and thus the promise of happiness for my respondents is not rooted in their personal shortcomings, dysfunctional childhoods, or insufficiently selfaware behaviours, but are shaped by structural and institutional forces that circulate in the field of unequal actors and opportunities. We should therefore re-conceptualise our understanding of the project of happiness from a strictly individualised one to "public happiness." Adrienne Rich first coined the term "radical happiness" to describe the joy when people shared a "sense of true participation in society" (Real Change News 2001). She drew on Arendt's notion of "public happiness" (On Revolution). Similarly, Judith Butler writing on "precarious lives" asserted that accepting the fragilities of life is what it means to be fully human (2006). Therefore, our vision for a perfect society should not strive toward a fascist fantasy of fully self-sufficient, able-bodied, atomised individuals, but rather recognise and celebrate that we all depend on each other in a deep and profound way.

We should therefore utilise Eve Sedgwick's "universalising view" of disability to replace the "minoritising view." As Rosemarie Garland-Thomson beautifully put it, disability is the most human of experiences, which demands that human interdependence and the universal need for assistance be figured into our conversations about rights and subjectivity $(2002,10)$. In a quote attributed to anthropologist Margaret Mead, she famously identified, as the earliest evidence of human civilisation, the excavated skeleton of a human with a broken femur bone that healed. It means that someone carried that person to a safe place and took care of them long enough for the bone to grow back together. In the times of COVID-19 pandemic, it has become even clearer that our survival and well-being is dependent on our ability to collaborate and to create networks of mutual care and support. Good health and thriving of every one person is dependent on access to healthcare, shelter, safety, and decent living conditions for all. 


\section{References}

"Adrienne Rich: Standing at the Intersection of Art and Activism," Interview by Pat Simpson, Michele Marchand, and Anitra Freeman. Real Change News, April 19, 2001 https://www.english.llinois.edu/maps/poets/m_r/rich/onlineints.htm

Ahmed, Sara. The Promise of Happiness. Duke University Press, 2010

Arendt, Hannah. On Revolution. Penguin Classics, 2006.

Brown, Adrienne Maree and Walidah Imarisha, eds. Octavia's Brood. Science fiction stories from social justice movements. AK Press, 2015

Butler, Judith. Precarious Life: The Powers of Mourning and Violence. Verso, 2006

Davies, William. The Happiness Industry: How the Government and Big Business Sold Us Well-Being. Verso, 2015

DePaulo, Bella. Singled Out: How Singles are Stereotyped, Stigmatized, and Ignored, and Still Live Happily Ever After. St. Martin's Press, 2007

Dolan, Paul. Happy Ever After: Escaping the Myth of the Perfect Life. Allen Lane, 2019

Ehrenreich, Barbara. Bright-sided: How Positive Thinking Is Undermining America. Picador, 2010

Emens, Elizabeth F., "Compulsory Sexuality," 66 Stan. L. Rev. 303, 2014

Essig, Laurie. Love, Inc. Dating Apps, the Big White Wedding, and Chasing the Happily Neverafter. University of California Press, 2019

Friedan, Betty. The Feminine Mystique. W.W. Norton Company, 1963

Fricker, Miranda. Epistemic Injustice: Power and the Ethics of Knowing. Clarendon Press, 2007

Garland-Thomson, Rosemarie, "Integrating Disability, Transforming Feminist Theory," NWSA Journal 14(3), Feminist Disability Studies (Autumn, 2002): 1-32

Hochschild, Arlie Russell. The Managed Heart: Commercialisation of Human Feeling. University of California Press, 2012 (first published in 1985)

Illouz, Eva. Why Love Hurts: A Sociological Explanation. Polity, 2013

Kislev, Elyakim. Happy Singlehood: The Rising Acceptance and Celebration of Solo Living. University of California Press, 2019

McRuer, Robert. Crip Theory: Cultural Signs of Queerness and Disability. New York University Press, 2006

Sandal, Carrie, "Queering the Crip or Cripping the Queer?: Intersections of Queer and Crip Identities in Solo Autobiographical Performance," GLQ: A Journal of Gay and Lesbian Studies 9 (12), 2003: $25-56$

Sedgwick, Eve Kosofsky. Epistemology of the Closet. University of California Press, 1990

Segal, Lynne. Radical Happiness: Moments of Collective Joy. Verso, 2018

Solnit, Rebecca. Men Explain Things to Me. Haymarket Books, 2014

Shatalova, Oksana and Georgy Mamedov, eds. Sovsem Drugie. Sbornik feministskoi i kvir-fantastiki [Utterly Other. A collection of feminist and queer science fiction]. Bishkek: STAB-Press, 2018

Shchurko, Tatsiana. "Compulsory Motherhood': the Female Reproductive Body as Regulated by the State (Based on the Analysis of the Newspaper 'Sovetskaia Belorussiia')," Laboratorium, 2, 2012: 69-90 
Kohl 6.2

200 Timofeeva, Daria. "In Kyrgyzstan a mother and her two children have burned alive. Neighbours suspect suicide due to a family conflict," Current Time, 13 February 2019 https://www.currenttime.tv/a/29767997.html 